\title{
China's Influence in Asia: How Do Individual Perceptions Matter?
}

\author{
Jinrui $\mathrm{Xi}^{1} \cdot$ Christopher Primiano ${ }^{2}$
}

Received: 27 December 2019 / Accepted: 21 April 2020 / Published online: 2 June 2020

(C) Springer Nature B.V. 2020

\begin{abstract}
Taking pride in the vibrancy and transparency of democracy, countries such as the USA have prioritized the spread of democracy in its foreign policy. The admirable impact that this political agenda has garnered across the globe pushes us to ponder what China would offer as it aspires for a more prominent position on the international stage. Particularly, how would China foster its image in Asia and, as a result, earn a favorable voice and even all-out support from Asian countries, countries economically underdeveloped and politically volatile? This paper sets out to answer this question by critiquing whether or not popular perceptions of China's political system impact how Asians perceive China's influence in general. Conducting statistical analysis using the fourth wave of Asian Barometer Survey (2016) to assess the above argument, we find that Asians who lend their support for China are more keen to the economic opportunities that China's growing economy offers their country than they are of China's political system. In short, China's authoritarian regime type does not factor into Asians' perception of China, except when individuals are highly educated with and committed to democratic principles.
\end{abstract}

Keywords China's image $\cdot$ Economic power $\cdot$ Political influence $\cdot$ Asia

\section{Introduction}

China's rise to the second largest economy and its increasingly more active engagement with the world have prompted mixed reactions from the international community. While many, including scholars, journalists, and officials, have sounded alarms for China's rapid rise in the international system, others appear to be more optimistic and welcoming of China's rise as an opening for more opportunities. This mixed reaction is particularly pronounced in Asia, a region complicated by its political variation,

Christopher Primiano

cbprimiano@gmail.com

1 Jinan University, Guangzhou, China

2 Department of International Relations, KIMEP University, Almaty, Kazakhstan 
religious diversity, and economic disparity. While most Asian countries tend to view China as a workable and promising economic partner, some remain skeptical about China's rise, cautioning the potential threat that a stronger China might pose to the region's stability and development.

Owing to the spectacular economic growth that China has achieved in the past three decades, the Chinese government, especially under Xi Jinping, has sought to advance its interests in world affairs with a more assertive foreign policy. Observers argue that, among others, China's uncompromising claim on the maritime territory in the South China Sea, and particularly the rapid modernization of its military, has invited tensions and frictions among its Asian neighbors. In its most recent gathering of the National People's Congress in March of 2018, China increased its defense budget by $8 \%$ [27]. As Yahuda posits, "with its greater military power, China is more actively asserting its claims against weaker neighbors [43: 450]." For instance, in Sino-Japan relations, scholars contend that China has grown more aggressive against Japan in recent years, especially over the disputed Diaoyu Islands (Senkaku Islands in Japanese) [18, 46].

Those concerned with a more powerful China tend to see China's increased military spending and rapid modernization with alarm, for the rise of a non-democratic country might bring more unpredictability to the region. For instance, while The New York Times published only four articles on "Chinese military spending" in 1999, its articles on the same subject reached as many as thirty in 2013 [see 40: 301-302]. According to Yang and Liu's study of major American newspapers that focus on "China threat" from 1992 to 2006, military or strategic issues appear to be the most prominent factor, especially since 1995 , that helps portray China as a threat to the USA [40, 45].

Others, however, view China's rise in a more positive light. They expect that, as a soaring economic giant, China will allow more opportunities for trade and economic cooperation with the entire region. China's economic boom not only propels more Chinese commercial investments into these Asian countries, but it also facilitates systematic financial aggregation at the international level to improve basic infrastructure in underdeveloped Asian countries. One of such signature moves is China's creation of the Asia Infrastructure Investment Bank (AIIB). The AIIB, however, raised concerns in the USA that the AIIB might be an attempt to replace the Western-created International Monetary Fund (IMF) and the World Bank.

While these perceptions are not entirely baseless, they are mostly fostered by political leaders and elite business groups. ${ }^{1}$ Much less research looks into public opinion toward China's influence in Asia. The main research question that we answer in this article is as follows: How do popular perceptions of China's political system and of its development model among China's neighbors affect popular opinion toward China's influence? We define China's influence in this research as a confluence of both political and economic influence. We do not distinguish between political and economic influence, not only because empirical data for this question is yet to be made available, but also because when trickled down to individual level data, China's influence toward a given country is mostly viewed in macro-geopolitical fashion. Individuals are less likely to distinguish between the two dimensions of influences.

\footnotetext{
${ }^{1}$ Berinsky [1: 984] identifies this notion as "elite cue theory," which hypothesizes that members of the mass public look to prominent political actors as references before identifying their positions on the country's stance toward war. Statements by political leaders can thus have a significant impact on public opinion.
} 
In this article, we answer these questions by examining the latest wave of the Asian Barometer Survey data (ABS 2014), which is the latest wave of empirical data available for the Xi Jinping era. ${ }^{2}$ As most of the pressing regional issues arose post2012, after Xi came into office, it is thus imperative to highlight that the time frame under this study is the Xi Jinping era, ${ }^{3}$ when his leadership has embarked upon a fundamentally different course from his predecessors regarding foreign policy objectives. In this article, we employ a quantitative research approach to assess how Xi's striving for achievements (or SFA) fares with our analysis of the 4th wave survey data.

Employing the newest ABS data offers valuable insights to our research inquiry because of the following three reasons. First, 2012 marked an important threshold in international relations in Asia. The previous wave of Asian Barometer Survey (wave 3) was conducted from 2010 to 2012, prior to this threshold. China has experienced fundamental changes in its role in the world since 2012. For instance, its critical contribution to the BRICS and the AIIB, as well as Xi's ideological construction of the China Dream, took place after Xi came into office. Second, the maritime dispute between the Philippines and China over the Scarborough Shoal intensified in 2012. Likewise, China's island building and land reclamation in the South China Sea captured wide international attention after 2012. Third, scholars have argued that China's assertiveness in its foreign policy became more evident at this time $[5,9,18$, $43,46,47]$. Thus, the previous waves of the Asian Barometer Survey data can no longer account for the most contemporary changes in the Asia Pacific. The fourth wave of ABS, which we now employ with its most contemporary time frame, warrants our current examination.

We contend that the theoretical perspective that one espouses in understanding international relations in general has a significant impact on how one views a rising in China's influence in particular. In line with the liberal emphasis, represented by Joseph Nye and others, that regime type matters, we find in this study that, first, China's economic power stands out as the most prominent factor turning respondents to view China's influence as positive; second, how China's regime type affects Asians' perception of China's rise is conditioned by how democratically aware the respondents are themselves. Put differently, China's authoritarian regime type does not seem to bother respondents in the nine Asian political entities surveyed here who do not embrace democratic values. By contrast, for respondents who are highly aware of the core democratic values, the results show that China's authoritarian political regime tarnishes its international image. Among the democratically aware respondents, the more the respondents view China as democratic, the more likely they will view China's influence as positive, all else equal.

To execute this inquiry, this article proceeds in the following sections. First, we provide background information as well as the literature review of China's rise in the context of Asia. We situate our focus in the context of Xi Jinping's fundamental foreign policy changes from that of his predecessors. Second, we present the theoretical framework of our article, elaborating on how China's economic might and political structure might affect Asian respondents' perception of China's rise. Third, we present

\footnotetext{
${ }^{2}$ Countries or regions included in the fourth wave are Mongolia, Myanmar, Taiwan, Philippines, Cambodia, Korea, Singapore, Malaysia, and Thailand.

${ }^{3}$ Xi became CCP General Secretary in November 2012 and then inaugurated in March 2013.
} 
our research design and empirical findings. The last section concludes this study with an emphasis on the core findings of this research inquiry and directions for future research.

\section{China's Rise}

In the aftermath of the Cold War, China emerged as a possible challenger for the USA regarding economic and security issues. Against this background nested the China threat argument. In the 1990s, heated debates focused upon whether or not the USA should aim to contain China with economic and security measures or engage China with trade and multilateral collaboration in international organizations. Scholars in the school of realism argue that states remain on guard regarding other states. For realism, today's friend may be turn into a foe tomorrow. On the important topic of trade, in contrast to liberal IR theory, realists tend to view trade as an opportunity to empower trade partners to become tomorrow's opposing challengers. In addition, the wealthier China becomes, according to realism, the more international influence it will seek. Many liberals, however, espouse the view that trading with China is a viable option, because China will seek to avoid military confrontation in order to maintain the economic gains afforded by trade. For China threat proponents, of which many are realists, the USA should be concerned about a rising China due to its authoritarian regime type and the political ambitions it might have exhibited to challenge the interests of the USA. Many China threat proponents argued that as China becomes more powerful, the Chinese government will be more assertive in posing a serious challenge to the USA.

While the China threat argument emerged in the 1990s, the "Chinese assertiveness" argument emerged in the time period after the 2008 financial crisis and has received ample attention since Xi Jinping came to office in China in 2012. In the literature, it is generally accepted that there has been a change toward assertiveness in China's domestic and international politics under Xi Jinping, for Xi has embraced a more active foreign policy approach than his predecessors $[11,44]$. In particular, Xi has departed from Deng's mantra of Keeping a Low Profile (KLP) and Bide the Time (taoguangyanghui) and instead has embraced the strategy of "Striving For Achievements" (SFA) (see [44]).

According to Yan Xuetong, a leading international relations scholar in China, whereas KLP focused on economic development, SFA aims to advance China in world politics [44]. Since coming to office, Xi has initiated a number of major foreign policy objectives, such as the Belt and Road Initiative (BRI), ${ }^{4}$ his pledge of $8000 \mathrm{UN}$ Peacekeeping personnel for a standby unit, the China Dream, ${ }^{5}$ and the AIIB, all of

\footnotetext{
${ }^{4} \mathrm{Xi}$ announced the Belt and Road Initiative in 2013, just a few months after his inauguration into office.

5 Xi's China dream chiefly aims for "national rejuvenation" in world politics (see [44]). Xi explained that "the China dream, after all, is the dream of the people. We must realize it by closely depending on the people. We must incessantly bring benefits to the people" (quoted in [41]). This is the political agenda mapped out of his China Dream: "We must make persistent efforts, press ahead with indomitable will, continue to push forward the great cause of socialism with Chinese characteristics, and strive to achieve the Chinese dream of great rejuvenation of the Chinese nation." For Xi's China dream, it is premised on the notion that the CCP is the only game in town. With the China dream, there are domestic and international implications [15].
} 
which reflect Xi's quest for more international influence. These initiatives that Xi has advanced demonstrate a fundamental difference with his predecessors in regard to his approach to international politics. Lauding the strategy of SFA, Yan [44] argues that it has excelled and exceeded expectations with its remarkable success. ${ }^{6}$

While scholars disagree on when exactly China became more assertive in its foreign policy, a number of them pinpoint the year of 2012 as the time when China enacted a more confident policy platform in its foreign relations. A number of them argue that China has acted assertively in the South China Sea [8, 14, 43]. Cruz De Castro argues that China employed "bullying tactics" in the maritime area by pressuring states in the South China Sea (SCS) to yield to Chinese interests on its disputed maritime territories. For instance, the Chinese navy has acted against the Philippines in the SCS, as the Chinese coast guard used water cannons to remove Filipino fishermen from areas that China claims [14, 8, ]. Other scholars such as Friedberg [17], Mastro [21], and Chen and $\mathrm{Pu}$ argue that Chinese foreign policy in general is assertive. The term "assertive" is defined by Chen and Pu as: "a confident and direct way to defend one country's rights or claims [12: 177]." Many in the assertive camp essentially agree with Friedberg's view: "In recent years, Beijing has repeatedly chosen to escalate ongoing disputes rather than wind them down." [17: 135] Many point to China's recent stance and actions regarding maritime disputes in the SCS as evidence of such assertiveness and the building of artificial islands for the ostensible purpose of projecting military force.

In addition, China's neighbors, member countries of the Association of Southeast Asian Nations (ASEAN) in particular, grew concerned about China's actions [31]. Some (such as Chan and Li) argue that China's actions in the South China Sea have not been well-received by states in the region [10]. According to many of the scholars who argue that China has embraced this new assertiveness, it is $\mathrm{Xi}$ who is largely responsible for the aggravated situation in the South China Sea and for the rising concerns from what the USA, Japan, and India perceive as offensive Chinese actions, such as China's stance on the Diaoyu Islands, the claim that the entire South China Sea belongs to China [10]. ${ }^{7}$ For instance, Southeast Asian states are developing and purchasing antiaccess and area-denial capability armaments due to, in part, China's actions in the SCS. An impending arms race in the region in response to China's military ascendancy might inflame a series of disputes and unpredictable conflicts [42]. However, there is not a consensus that there is an arms race or that there will be an arms race. Bitzinger, for example, argues that despite the increase in military spending in Southeast Asia, due to the concern of China's military power, this does not fit the definition of an arms race [4: 50, 61]. Recently, the Chinese government has stated that the South China Sea has belonged to China for thousands of years, and thus, China's actions in the SCS fall within its sovereign territory, according to the Chinese government.

Regarding the Philippines, Malaysia, and Singapore, we see some variance in their bilateral relations with China. For example, under the previous president of the Philippines, Benigno Aquino III, there was tremendous tension between the Philippines and China. The bilateral tensions or un-coziness melted with Duterte's election into office in 2016 [29]. The Philippines serves as the most visible front

\footnotetext{
6 2014: 153 .

${ }^{7}$ For the argument that China has not become more assertive in the 2009-2010 time period or in recent years, see [19]. Jerden argues that China demonstrated assertiveness long before 2008 [19].
} 
battlefield for the USA-China rivalry in Southeast Asia in that Duterte's stark shift of foreign policy from pro-USA, that of his predecessor, to pro-China reflects the calculations of a regime that incidentally sits on the regional geopolitical fault lines. As the Chinese government wants to reduce the USA's military presence in East Asia and the South China Sea in particular, it welcomed Duterte's new approach with China. Given Duterte's bellicose approach toward the USA, this only helps China with possibly containing the USA's influence in general and its military presence in the region in particular. The USA's hub and spoke military alliance system in East Asia, given that it is in China's backyard, is of great concern for the Chinese government. Other states in Southeast Asia have not embraced the confrontational approach with the USA that Duterte has, as many states want to engage China for trade and economic assistance and at the same time engage the USA on security matters. Such states, in other words, are engaged in hedging. Hedging allows for ties with both the USA and China, with no need to choose a side. For example, with the case of Malaysia, we see how the Malaysian government has bargained with China regarding BRI projects to obtain a better outcome for Malaysia.

\section{Theoretical Framework}

The different schools of thought in the studies of international relations perceive a rising China in quite different ways. Realists, especially offensive realists, of which John Mearsheimer is the leading proponent, view China as a threat [22]. Many realists argue that capabilities are essential in explaining why states act differently [38]. Powerful states act because they possess such power, and weak states do not do so because they cannot. This is the formula that realists often apply in predicting how a rising China would act in its foreign policy. Realism, receiving wide attention in both the media and the government, suggests that an increasingly more prosperous China does not necessarily introduce peace to the international community [33]. Schweller and Pu's summary of the realist perspective on rising powers in general and a nondemocratic China in particular indicates a deeply entrenched sense of insecurity in international relations, "Whatever their true intentions, rapidly growing states often appear as threats to their neighbors, as well as to the hegemon and its allies [35: 43]."

There has been ample debate regarding the importance of, or the lack thereof, public opinion influencing the country's foreign policy. In this debate, stark contrasts exist between how liberals and realists view public opinion influencing a country's foreign policy or actions in international politics. The founder of neorealism, Kenneth Waltz, argued that it is the anarchic international system that impacts how states act internationally. Waltz's third image, which is the image he emphasized, focuses on how power balances in the international system and does not devote attention to domestic public opinion. Instead, it focuses on the systemic level or international level [38]. Liberals, unlike realists, argue that domestic factors, such as public opinion, are significant. Leading liberal IR scholar Bruce Bueno de Mesquita argues that political leaders actboth domestically and internationally - in a way that aims to ensure that they remain in power. In democracies, this means that leaders must consider public opinion in international politics. For non-democracies, however, public opinion affects foreign policy making when authoritarian leaders work to appease domestic political rivalries 
[6]. For liberal scholars, democratic leaders need to have one eye on domestic opinion and one eye on the international circumstances [30].

Cho and Jeong argue that one of the main reasons why people in Asia have improved their views of a rising China is China's economic growth [13]. We reiterate Cho and Jeong's argument that China's rise through economic development is winning support from Asian countries. Individuals who view China as an economic power tend to see China's influence as positive, for the inflowing Chinese investments offer tangible income incentives to Asians who are struggling with making ends meet. In a region of mostly developing economies, which are seeking opportunities to improve the status quo, most Asians either have yet to foster democratic awareness or compromise desires of democratic institutions to social stability and economic development. In many instances, the urgent need for economic development takes priority over political development. For instance, a farmer would rather see economic issues be advanced than an abstract concept such as democracy. This argument more broadly applies to many countries in Asia, showing that many Asians prefer the urgent need for economic development more than political development.

Shin and Park, using wave 2 of the Asian Barometer Survey, find that most East Asians prefer economic growth over democracy when given the choice [36]. Thus, we anticipate that most Asians still view China's economic growth as a positive parameter in evaluating China's influence on their country in general. This issue of winning support from Asian countries is related to the issue of the Asian values' emphasis on economic development instead of political development. As we mentioned in the paragraphs above, economic development is viewed with a higher priority than political development in many Asian countries.

- H1: Respondents who see China as the future development model for their country are more likely to see China's influence as positive than those who do not see China as their model, all else equal.

We contend that how the public in Asia see China's political system has an effect on how they view China's influence on their country. In other words, individual perception of the unique political structure of China might affect how people view China's legitimacy in the region. Many see China's centralized political power in the hands of the Chinese Communist Party (CCP) as worrisome in that a risen and empowered China may engender regional stability and threaten the national security of certain countries. Primarily, the logic lies in how non-democracies function in foreign policy decision-making. Smaller countries in a region may worry that a non-democratic superpower, easily swayed by the personal ambitions of its leaders and potentially charged with aggressive nationalism agendas, may paralyze the balance of power that has previously kept every member state in the region in check. As popular distrust toward a given political structure usually sinks deep into individuals' political preference and is therefore hard to change, we argue that, despite China's consistent statement and actual practice of peaceful foreign policy, individuals disinterested in China's political system may hold markedly different views of China's influence in their country.

The theoretical underpinnings of this contention are mainly derived from the theory of democratic peace. That democracies do not fight each other is in a large part due to 
the significant level of popular trust between two democracies. Lack of such popular trust for the Chinese government, however, opens the spectrum of popular imagination to fear and insecurity.

Russett and Oneal explain why democracies are more peaceful, "People living in a democracy know that the citizens of other democracies share norms of limited selfgovernment, civil liberties, and democratic transparency." When democracies do go to war, it is usually with non-democracies [34: 67]. In the same vein, Tomz and Weeks conducted a survey regarding how people in the USA and the UK view military action against other countries. They find that "individuals are substantially less supportive of military strikes against democracies than against otherwise identical autocracies [37: 849]." They asked participants if they would approve or disapprove an attack on country X's nuclear facilities in a preemptive act. Participants were more likely to support a military attack on a non-democracy than a democracy. In other words, democracy is salient regarding willingness to use military force-not other issues [37]. A central finding useful for our focus here is that "citizens in democracies distrust dictators and have fewer moral reservations about using force against them [37: 863]."

Distrust toward the Chinese political system poses a formidable challenge to China's soft power outreach. Nye contends that China is lacking in soft power due to its lack of political openness. In contrast to the case of the USA whose soft power comes mostly from non-state actors, such as Hollywood, pop culture, and higher education, according to Nye, China lacks similar cultural products that draw resonance among the Asian populations. ${ }^{8}$ For instance, China's universities are not as competitive as America's. Very importantly for Nye, China lacks NGOs that can help spread the core values that China may deem as essential for its international exploration. Nye argues that so long as China continues with, for example, aggressive actions in the SCS, establishing Confucius Institutes will not help China's soft power advance. In the case of the USA's soft power, Nye explains the reason why Turkey did not support the USA in the 2003 war with Iraq was the lack of soft power of the USA in Turkey [23, 25]. Following the same logic as Nye, we argue that popular distrust of China's unique political system holds China back from advancing its soft power to individuals with strong convictions of democratic values [23, 25].

This effect, however, does not hold for individuals who are not yet democratically aware, either not educated with western democratic systems or disenchanted with the falling efficacy of democratic systems in western countries. For individuals who do not associate themselves closely with democratic values or government, China's unique political system does not matter in their perception of China's influence in their country. By contrast, we estimate some of them even favor China's influence in their country just because of the advantages that China's political system may offer. The centralized political control of the CCP, while analogues to pursuit of individual liberty and freedom, does offer the essential social order desperately needed in many Asian countries for development.

\footnotetext{
${ }^{8}$ Nye defines soft power as: "the ability to affect others to obtain the outcomes one wants through attraction rather than coercion or payment" [24: 94]. According to Nye, soft power is built on a country's, "culture, values, and policies" [24: 94]. For example, if a country has good human rights policies or is welcoming with its immigration policies, then that serves to advance that country's foreign policy.
} 
- H2: Respondents who see China as more democratic are more likely to view China's influence on their country as positive than those who see China as less democratic, all else equal. This is less the case for individuals who are not democratically aware.

\section{Research Design}

To test the above hypotheses, we use the latest (4th) wave of the Asian Barometer Survey (ABS) data collected from nine Asian political entities in 2014. The ABS data randomly selects around 1200 respondents ${ }^{9}$ from each of the nine countries (and regions) and collects respondents' personal opinion on a variety of subjects, ranging from social behavior and economic development to political preference. ${ }^{10}$ In this analysis, the total number of respondents from all nine entities is 11,551. This dataset is useful for this study because it offers the essential information on the key variables for the empirical analysis. This empirical analysis at the individual level sheds light on how citizens in Asian countries see China's influence on their own countries and what factors affect such public opinion.

The dependent variable for this study is China_Influence, a dummy variable coded as 1 if the respondent regards China's influence on his/her country (China's influence below) as positive and 0 if negative. The vast majority (62\%) of all the respondents in the nine Asian countries (and regions) regard China's influence on their country as positive while the remaining $38 \%$ see China's influence as negative. This simple finding shakes the common and pessimistic perception of China's international image in Asia among many scholars.

Public opinion of each country on China's influence is presented in Fig. 1. In six of the nine countries (and regions) surveyed, the majority of the people rate China's influence on their country as positive, while in the remaining three, namely Mongolia, Myanmar, and Taiwan, only a minority of the people see China's influence in the same light. Thailand offers the most favorable public opinion with as high as $93 \%$ of all its respondents seeing China's influence as positive. Malaysia comes next to Thailand with the second highest percentage of respondents who see China's influence as positive. By contrast, Mongolia has the least optimistic population toward China's influence. As many as $70 \%$ of the respondents from Mongolia treat China's influence as negative, and only $30 \%$ see China's influence as positive. Myanmar comes next to Mongolia with the next highest percentage of respondents with negative perception of China's influence. Regarding countries such as Malaysia, Singapore, and the Philippines, even though at the same time of the survey (2014) there were tensions between China and said countries regarding territorial disputes, the populace in such countries viewed China's influence on their country as positive. In the economics literature, workers appreciate foreign capital and investments. Thus, in the previously mentioned countries, especially the economically advanced city-state of Singapore, it is likely that such people view China's investments in a positive way and as the most salient issue, despite other contentious issues with China. Instead of prioritizing issues

\footnotetext{
9 The exact number of respondents ranges across countries.

${ }^{10}$ For more information regarding the data, refer to http://www.asianbarometer.org/.
} 
of high politics, it appears that survey participants prioritized tangible economic benefits for themselves and their country. Though the South China Sea territorial disputes have rippling effects upon public opinion toward China, these effects may have been overshadowed by China's massive influx of capital and economic opportunities. The economic incentives may have been weighted higher by the Asian population as compared with territorial disputes, which are usually framed in heavy-taste, costly yet highly political, nationalism rhetoric.

To test the hypotheses, we employ three independent variables: China_for_Dev, Per_CN_Demo, and Demo_Aware. China_for_Dev asks survey respondents whether or not China should be a model for their country's future development. It is operationalized as 1 if yes and 0 if otherwise. We use this independent variable for the analysis because China's rising economic influence in Asia powered by an authoritarian political system that promises a considerable level of political stability has become the biggest winning factor for China's popularity among its Asian neighbors. If this is true, at the individual level, survey respondents who see China as a future development model for their own country should be more likely to see China's influence in their country as positive.

Per_CN_Demo is individual's perception of China's democracy levels. Survey respondents are asked to rate on a scale of 0 to 10 how democratic China is, with 10 being the most democratic and 0 being the least. This variable is significant for our analysis, because it will show whether or not respondents' perception of China's democratic development has an effect on individuals' evaluation of China's influence on their country. We acknowledge that individuals may have poorly informed perceptions of the actual political outlook of China and, as a result, their understanding of Sino-Asia relations turns out to be uniquely shaped. But individuals' political perception, however departed it is from the reality, has political value in its own right.

Demo_Aware refers to the democratic awareness of the respondents. This is a composite variable constructed by adding the values of four sub-survey questions that focus upon democratic legitimacy and preference for democracy. These four subsurvey questions ask if respondents (1) Strongly agree, (2) Somewhat agree, (3)

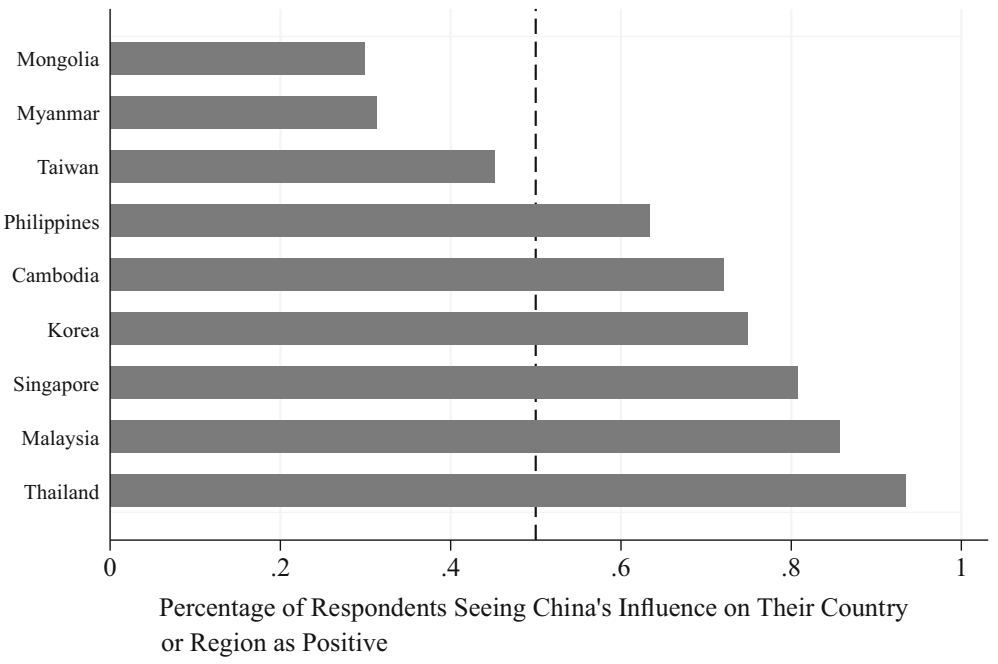

Fig. 1 Public opinion in Asia on China's influence (by country or region) 
Somewhat disagree, or (4) Strongly disagree with the following four statements: (1) We should get rid of parliament and elections and have a strong leader decide things; (2) Only one political party should be allowed to stand for election and hold office; (3) The army should come in to govern the country; (4) We should get rid of elections and parliaments and have experts make decisions on behalf of the people. As seen in Fig. 2, the largest value for this variable is 16 , which implies that the respondent has developed the most comprehensive level of democratic awareness, while the least value 4 implies the other end of the continuum.

This variable is included in the model interacting with $P e r_{-} C N_{-}$Demo. The effect that individuals' perception of China's democracy on how positive they see China's influence might be conditioned by how well they have fostered democratic awareness internally. For those who are well-educated on the principal values of democracy, how they see China's influence on their own country might be affected more effectively by their perception of China's regime type than those less educated on the values of democracy. If a democratic and transparent regime, to these respondents, is the prerequisite for establishing trustworthy foreign relations and economic ties, China, as an authoritarian state, might find it challenging to win trust from these respondents. Whereas to those who are less educated or less passionate about democratic values and principles, the outlook of China's political regime may affect them the least, in that their immediate concerns may not be whether China is a democracy, but rather revolve around how this country can economically benefit their country.

Descriptive statistics of all the variables are presented in Table 1.

A number of control variables are also included in this analysis to account for other factors that might have an effect on the dependent variable. The first two control variables are Know_Other and Own_Demo. Know_Other measures how closely respondents follow political events in other countries. Those who have access to and are then informed by information of other countries make more calculated decisions on China's influence. Own_Demo is a variable that measures how the respondent evaluates the democracy level of his/her own country. This variable is included because how

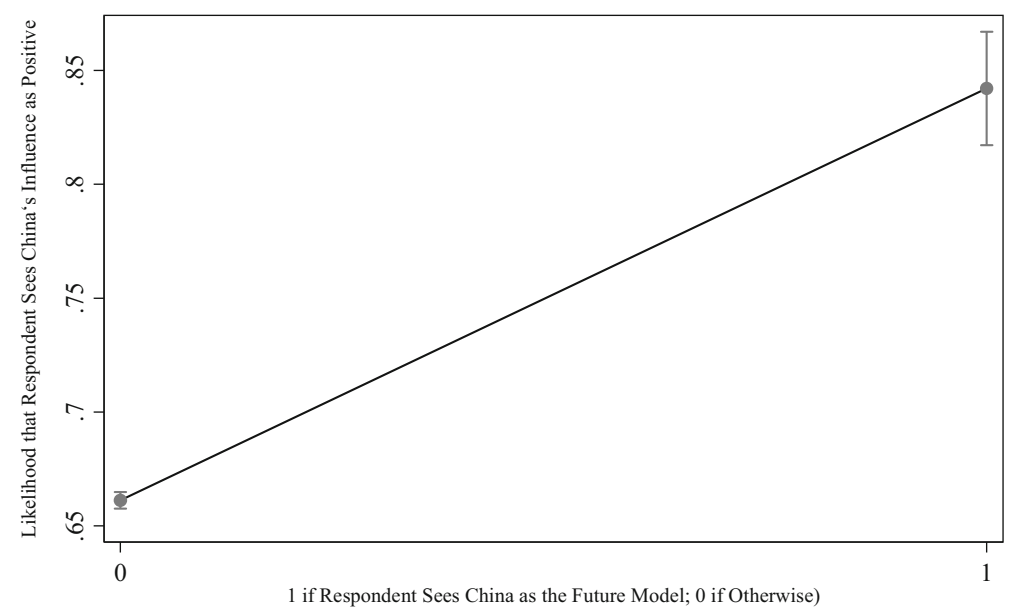

Fig. 2 Predicted respondent perception of China's influence (by how respondents see China as a development model) 
Table 1 Descriptive statistics of variables

\begin{tabular}{|c|c|c|c|c|c|}
\hline Variable & Obs & Mean & Std. Dev. & Min & $\operatorname{Max}$ \\
\hline CN_Inf_2 & 10,027 & 0.6244141 & .484298 & 0 & 1 \\
\hline China_For_Dev & 11,551 & 0.1013765 & .3018397 & 0 & 1 \\
\hline Know_Other & 11,327 & 2.934934 & 1.205198 & 1 & 5 \\
\hline Own_Demo & 10,775 & 6.116752 & 2.108728 & 1 & 10 \\
\hline Geo_Location & 11,546 & 2.548935 & 1.153482 & 1 & 4 \\
\hline Gender & 11,547 & 0.4924223 & .4999642 & 0 & 1 \\
\hline Income & 10,781 & 2.579167 & 1.288442 & 1 & 8 \\
\hline Christian & 11,551 & 0.1595533 & .3662071 & 0 & 1 \\
\hline Muslim & 11,551 & 0.0799065 & .2711601 & 0 & 1 \\
\hline Buddhist & 11,551 & 0.5084408 & .4999504 & 0 & 1 \\
\hline Marital & 11,500 & 0.7729565 & .4189391 & 0 & 1 \\
\hline Edu & 11,536 & 5.716626 & 2.829908 & 1 & 10 \\
\hline Age & 11,547 & 43.25452 & 14.68986 & 17 & 108 \\
\hline
\end{tabular}

familiar respondents are with the political development of their own country might affect how they see China's influence. One who is well informed of his own democracy but disappointed by the neighboring countries might develop a sense of pride, which in turn affects our dependent variable, how he sees China's influence.

The second group of control variables accounts for the idiosyncratic characteristics of survey respondents, such as education, age, income, religion, marital status, gender, and geo-location. We believe that these idiosyncratic attributes matter for respondents' view of China's influence. For instance, age carries much significance in this analysis, because the older generation, especially in Taiwan, retains a stronger level of emotional attachment to the mainland. Their view of China's influence might differ quite significantly from the millennials. Education matters as well, in that more educated respondents have the inquisitiveness and resources to access information on other countries. Their perception of China's influence should look different from those less educated.

The last group of control variables are country dummies, controlling for the intervening effects of country-level attributes. For example, a historic animosity or fierce political rivalry between China and any of the nine Asian countries could trickle down to each citizen and cause change in the respondents' perception of China's influence. Countries more politically aligned with the west, such as the Philippines and South Korea, are probably more cautious in positioning China in the international stage.

\section{Analysis}

The unit of analysis is individual respondent. The effective number of observations is 8120 , after dropping observations with missing values. The binary dependent variable of the data requires that we perform a logistic regression model. The zero-one ratio of the dependent variable is 0.61 , which is within the proper balance range for logistic regression. I also perform the regression analysis with the data clustered at the country 
level, controlling for country-level factors. For instance, respondents in Malaysia might see China's influence on their country different than their counterparts, due to reasons specific to the country, such as the economy or culture. Findings of all four models are presented in Table 2 . While model 1 only contains the core variables, models $2-4$ incorporate control variables. While model 2 only includes control variables Know_Other and Own_Demo and other idiosyncratic variables, model 3 includes, in addition to what model 2 has already included, not only the interaction variable between Per_CN_Demo and Demo_Aware but also the other control variables. Model 4 adds country dummies.

As shown in Table 2, the core independent variable of this study, China_For_Dev, has a positive and statistically significant effect on the dependent variable, how the respondent sees China's influence. The null hypothesis that China_For_Dev has no impact on the dependent variable is rejected at the $1 \%$ level. The positive effect means that, as one expects China to be the future development model more, he/she is more likely to see China's influence on his/her country as positive. This implies that China's overall model, with its robust economic development under the particular political system, wins for China popular support. It provides China with a political leverage in the area of public opinion.

Substantively, holding all other variables at their mean, as one individual in any of these nine Asian countries (and regions) change to expecting China as the future development model for his/her country, the likelihood of him/her seeing China's influence as positive increases by $18 \%$ (see Fig. 2). This shows us that, at the individual level, whether respondents seek out China for their future development largely determines how they view China's influence. Respondents are much more likely to see China's influence in a positive light when it comes to overall development. This overall development means not only economic development but also effective governance and political stability. By contrast, those who do not intend or see China as a promising model for their countries' development tend to see China's influence as negative.

The second core independent variable in this analysis, Per_CN_Demo and Demo_Aware as an interaction variable, bears statistical significance in explaining the occurrence of the dependent variable. That the interaction variable has statistical significance on the dependent variable implies that the Per_CN_Demo and Demo_Aware together have an interactive effect on China's influence.

In a non-linear model like logit used in this analysis, it is not appropriate to directly interpret the relationship between the dependent variable and the independent variables as varied, while holding all other variables at a constant [2]. The most efficient and accurate approach is to compute the graph of the relationship between the interaction variable. This attempt is thus conducted in this analysis. The interaction effect of the two independent variables, Per_CN_Demo and Demo_Aware, is now more clearly presented. As shown in Fig. 4, the effect of perception of Chinese democracy is conditioned by how democratically aware the respondent is. For those with an extremely low sense of democratic values (setting the value of Demo_Aware at 3 for example), the effect is negative; the effect turns positive, however, as soon as respondents' democratic awareness grows beyond a certain threshold (Demo_Aware $=5$ ). For those espousing democratic values and upholding democratic principles, the more democratic they see China, the more likely they will see China's influence on their country as positive. 
Table 2 Logistic regression analysis of Asians' perception of China (clustered by country). Dependent variable: China's influence on respondents' own country, positive $(Y=1)$, if otherwise $(Y=0)$

\begin{tabular}{|c|c|c|c|c|}
\hline Independent variables & Model 1 & Model 2 & Model 3 & Model 4 \\
\hline \multirow[t]{2}{*}{ China_For_Dev } & $1.470 * * *$ & $1.377 * * *$ & $1.351 * * *$ & $1.005 * * *$ \\
\hline & -0.18 & -0.16 & -0.15 & -0.1 \\
\hline \multirow[t]{2}{*}{ China's Democracy } & $0.119^{* *}$ & $0.092 * *$ & $-0.143 * *$ & -0.066 \\
\hline & -0.05 & -0.05 & -0.07 & -0.06 \\
\hline \multirow[t]{2}{*}{ Demo_Aware } & 0.011 & 0 & $-0.091 *$ & $-0.123^{* * *}$ \\
\hline & -0.04 & -0.03 & -0.05 & -0.03 \\
\hline \multirow[t]{2}{*}{ Know_Other } & & 0.099 & 0.096 & -0.039 \\
\hline & & -0.07 & -0.07 & -0.05 \\
\hline \multirow[t]{2}{*}{ Own_Demo } & & $0.104 * * *$ & $0.103 * * *$ & $0.044 *$ \\
\hline & & -0.04 & -0.04 & -0.03 \\
\hline \multirow[t]{2}{*}{ Geo_Location } & & 0.018 & 0.015 & $0.100 * * *$ \\
\hline & & -0.14 & -0.14 & -0.04 \\
\hline \multirow[t]{2}{*}{ Gender } & & 0.076 & 0.081 & $0.075^{*}$ \\
\hline & & -0.08 & -0.07 & -0.04 \\
\hline \multirow[t]{2}{*}{ Income } & & 0.021 & 0.023 & $0.073 * * *$ \\
\hline & & -0.03 & -0.03 & -0.02 \\
\hline \multirow[t]{2}{*}{ Christian } & & 0.234 & 0.229 & $-0.229 * * *$ \\
\hline & & -0.26 & -0.25 & -0.08 \\
\hline \multirow[t]{2}{*}{ Muslim } & & $0.922 * * *$ & $0.919 * * *$ & -0.094 \\
\hline & & -0.25 & -0.25 & -0.17 \\
\hline \multirow[t]{2}{*}{ Buddhist } & & 0.05 & 0.041 & 0.032 \\
\hline & & -0.36 & -0.36 & -0.11 \\
\hline \multirow[t]{2}{*}{ Marital } & & -0.025 & -0.022 & $0.180 * * *$ \\
\hline & & -0.14 & -0.14 & -0.06 \\
\hline \multirow[t]{2}{*}{ Edu } & & -0.009 & -0.008 & 0.002 \\
\hline & & -0.01 & -0.01 & -0.01 \\
\hline \multirow[t]{2}{*}{ Age } & & 0.003 & 0.003 & 0 \\
\hline & & -0.01 & -0.01 & -0.01 \\
\hline \multirow[t]{2}{*}{ Interaction Term (Demo_Aware and China's Demo) } & & & $0.020 * * *$ & $0.013 * *$ \\
\hline & & & -0.01 & -0.01 \\
\hline \multirow[t]{2}{*}{ Korea } & & & & $1.472 * *$ \\
\hline & & & & -0.62 \\
\hline \multirow[t]{2}{*}{ Mongolia } & & & & -0.684 \\
\hline & & & & -0.54 \\
\hline \multirow[t]{2}{*}{ Philippines } & & & & $1.075^{*}$ \\
\hline & & & & -0.58 \\
\hline \multirow[t]{2}{*}{ Taiwan } & & & & 0.205 \\
\hline & & & & -0.58 \\
\hline \multirow[t]{2}{*}{ Thailand } & & & & $3.043 * * *$ \\
\hline & & & & -0.57 \\
\hline Singapore & & & & $1.885^{* * *}$ \\
\hline
\end{tabular}


Table 2 (continued)

\begin{tabular}{lcccc}
\hline Independent variables & Model 1 & Model 2 & Model 3 & Model 4 \\
\hline Cambodia & & & & -0.61 \\
& & & & $0.980^{*}$ \\
Malaysia & & & -0.57 \\
& & & & $1.878^{* * *}$ \\
Myanmar & & & & -0.55 \\
& & & & -0.577 \\
cons & -0.218 & -1.199 & -0.08 & -0.54 \\
& -0.68 & -1.03 & -1.04 & \\
$N$ & 8667 & 8119 & 8119 & 8119 \\
$\chi^{2}$ & 87 &. & $\cdot$ &. \\
\hline
\end{tabular}

Table entries are logistic regression estimates of Asians' perception of China's influence on their own countries

Source: Asian Barometer Survey (2014)

${ }^{*} p<0.10 ; * * p<0.05 ; * * * p<0.01$

The data shows that only a small percentage of respondents fall under the democratic awareness threshold (Demo_Aware $\leq 5$ ). Among the 8120 observations in this analysis, only $270(3 \%)$ of them hold extremely low democratic awareness. Thus, the following analysis mainly focuses on the respondents with considerably high democratic awareness (see Fig. 3).

Substantively, among those with the highest level of democratic awareness, as respondent's perception of China's democracy increases by one point, his/her likelihood of seeing China's influence as positive increases by $3 \%$, all else equal. For two respondents with exactly the same attributes, and the same (the highest) level of democratic awareness, the one who sees China as completely democratic is $29 \%$ more

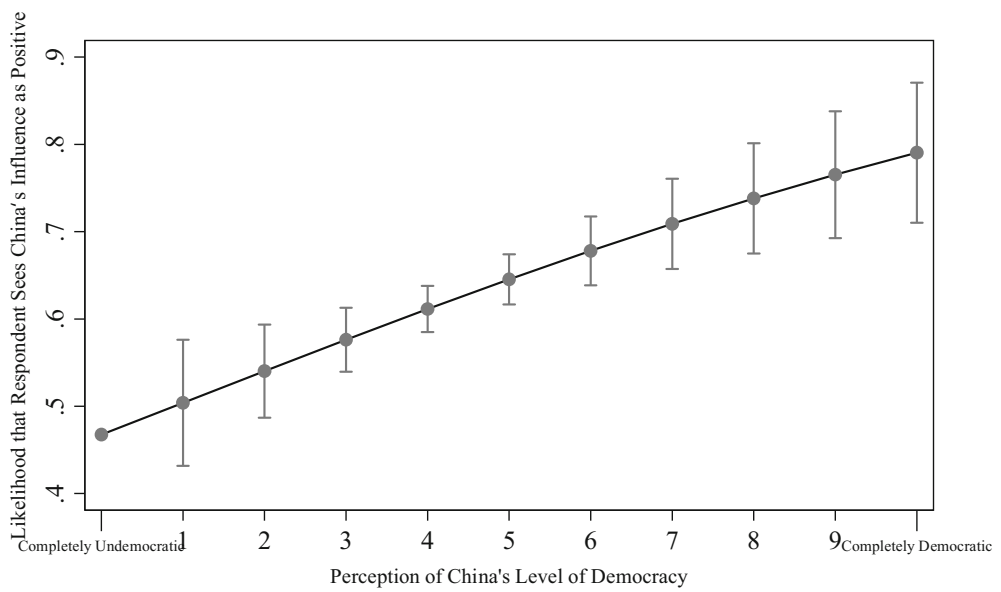

Fig. 3 Predicted respondent perception of China's influence (among respondents whose democratic awareness is the highest) 
likely than the one who sees China as completely undemocratic to view China's influence on their own country as positive.

In the next step of the analysis, we compute the marginal effect of Per_CN_Demo conditioned by Demo_Aware_2 (Fig. 4). Such a computation is necessary for identifying the threshold of the Demo_Aware_2 beyond which the effect of Per_CN_Demo surges statistically significant above 0 . As shown in Fig. 5, the threshold value of Demo_Aware_2 is identified at nine, implying that, for observations with Demo_Aware_2 value lower than nine, respondents' perception of China's political system does NOT bear any relationship with how they evaluate China's influence on their country. Once we pin down the threshold, tabulation of the percentage of respondents whose Demo_Aware_2 values sit below nine is $13.7 \%$. This tells us that, for the vast majority of the surveyed population $(86.3 \%)$, individual perception of China's political system has a significant effect on how China's influence is rated in general.

This indicates that how people in Asia see China's regime type, either being democratic or undemocratic, has a significant impact on whether they perceive China's influence as positive or not. In other words, whether people in Asia see China as a threat is impacted by their perceptional understanding of China's regime type. In this sense, China's political reform into a more democratic state will gradually increase China's standing on the international stage, all else equal. This finding is significant in that it shows the political challenge that Beijing faces when maximizing its influence on its Asian neighbors. Economic power can only travel a limited distance for Beijing to turn Asians' perception on China to positive. Fumbles in the campaign of political authority and popularity will likely cause Beijing struggles in its long-term plan to become a respected and recognized global leader.

The country dummy control variables show similar results to what we might expect from Fig. 1. The country dummies are included to account for the effect that country-

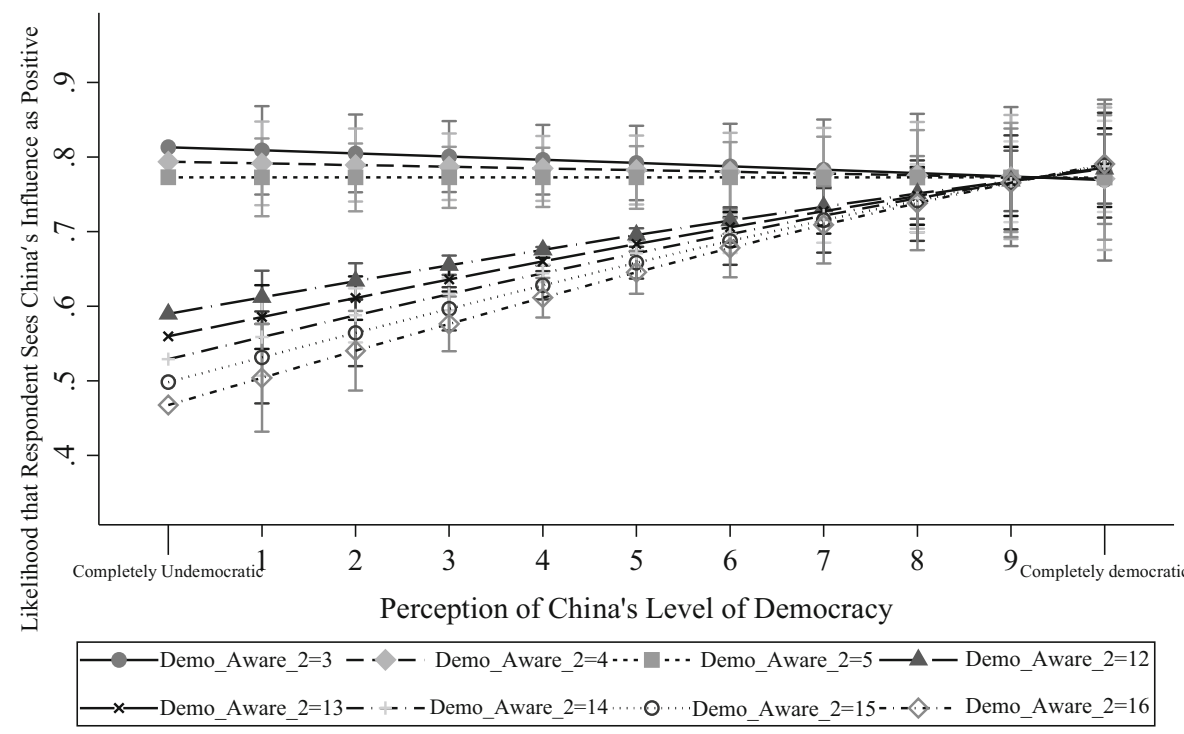

Fig. 4 Predicted respondent perception of China's influence (interaction between China's democracy score and Demo_Aware) 


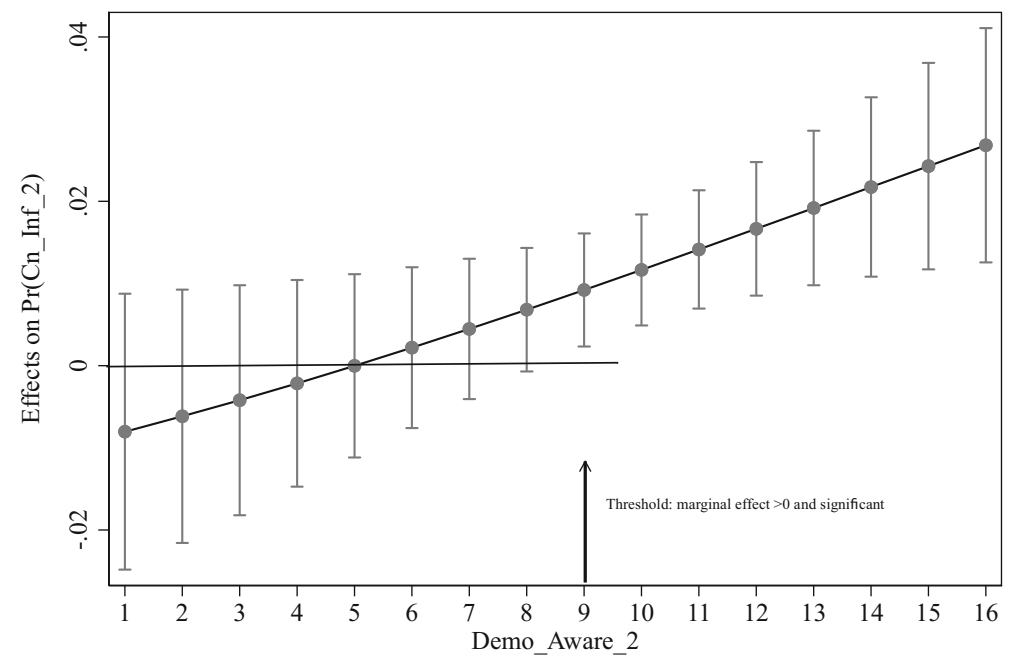

Fig. 5 Average marginal effects of Per_CN_Demo with 95\% CIs

specific attributes, as well as bilateral relations between China and the Asian countries, have upon the dependent variable. Among all nine countries or regions, Mongolia, Myanmar, and Taiwan are the only three that show negative signs, but without statistical significance. All other six countries show positive, statistically significant effect upon the dependent variable, implying that respondents from these countries, compared with the other three, see China's influence on their own countries as positive. This falls in line with the description in Fig. 1, where the majority of the respondents in all countries, except Mongolia, Taiwan, and Myanmar, see China's influence as positive. When the percentage of the entire population that sees China's influence in a positive light drops to become the minority, the overall atmosphere of public opinion toward China sours as well.

This distribution of public opinion across the countries is also a factor of bilateral relations between China and the other countries. Here we examine the three countries that do not have a majority of respondents seeing China in a positive light. In general, these three countries are more democratic according to the Polity IV scores than others. It is likely that the democratic political systems that characterize these countries set the respondents in these countries at odds with the authoritarian system in China. As a result, this finding provides further support to our thesis that different political systems do have an impact on how the civilians view other political systems.

The congruence of political systems between China and the respective Asian countries plays a critical role in the bilateral relations between two countries, as well as in public opinion toward China. Particularly, Mongolia and Tawain, the two places with the most political freedom according to the most updated assessment of Freedom House [16], possess the most skepticism of China. Myanmar, though not yet a mature democracy, was undergoing a breathtaking democratic transition when the survey was conducted in 2014 [7]. The prevailing democratic atmosphere highlighting democratic openings and freedom of speech in these countries likely sets respondents up for perhaps an elusive disdain for the opaque political system that characterizes the Chinese political system. This then further clouds individual's judgment over China's influence upon their own country. 
Besides the apparent political incongruence, China's bilateral relations with Mongolia, Myanmar, and Taiwan bear some deep historic scars. For instance, Mongolia has harbored a deep level of distrust toward China historically. It has long sought to maintain its foreign policy independence by balancing China against Russia, although that leverage has significantly decreased since China and Russia grew closer diplomatically post-1960s. To shore up its political leverage against China, Mongolia did not hesitate to invite the Dalai Lama, who is viewed with disdain by the Chinese government, for an official visit even in the midst of an economic meltdown in 2016 [3].

Cross-strait relations between the mainland China and Taiwan, as well as Taiwanese attitude toward mainland China, are fraught with concerns over political and military confrontations. Historically sandwiched between mainland China and the USA, Taiwan has served as a strategic political play card for the two giants. Similar to Mongolia, how Taiwan authorities walk the fine line between the USA and Beijing will impact not only the outlook of regional security but also how the Taiwanese see the mainland's influence upon that island. Despite Taiwan's increasing dependence upon the inflowing tourists from mainland China to boost its tourism industry, its public opinion toward mainland China remains skeptical across the board, as Taiwan is still overshadowed and even dominated by political considerations for cross-strait relations.

While the vast majority in the more democratic Asian countries tend to see China's influence on their own countries as negative, the least democratic ones stand on the other end of the spectrum. For instance, Thailand, the Southeast Asian country with a history of precarious democratic practices, is now ruled by the military after the 2014 coup [32]. The shared political critique of the imperialist West, in addition to many other factors such as closer and more direct economic ties, has provided the general context for the two countries to foster tighter bilateral relations. The shared geo-political interests in bilateral relations between China and Thailand lay the essential foundation for a more favorable Thai public opinion toward China's influence.

Among the countries examined in this paper, three of them share maritime territorial disputes with China: the Philippines, Malaysia, and Singapore. Surprisingly, despite the escalated disputes in the South China Sea around 2012, the three countries still maintain the majority seeing China's influence as positive.

Though not officially claimant to the South China Sea territories, Singapore sees these maritime disputes as its central concern, as its economy so heavily depends upon the commercial flows in and around Singapore's shores. Singapore's outright recognition of the arbitration ruling by Arbitral Tribunal in 2016 drew Singapore into the spotlight in the Asia neighborhood [26]. However, despite the diplomatic "fumbles" between the two countries, Singapore still remains a close partner with China in the region and continues to see China's influence in a positive light.

While the Philippines openly contests with China in the territorial issues in the South China Sea, its faltering relations with the USA have led to President Duterte's fallback toward closer ties with both Russia and China since taking office in 2016. Though Duterte came to office after the current survey was conducted, it is still suggestive of the overriding public resentment in the Philippines toward its previous foreign policy orientations. Coupled with the country's weak economic and military prowess [39], people in the Philippines still view China as a potential mutually beneficial partner. 
Among all Southeast Asian countries, Malaysia stands out in its active and constructive engagement with China. Its focus on economic cooperation with China has successfully overcome much of the national security concerns and ethnic tensions between the ethnic Chinese and the native Malays. As the first country in the ASEAN bloc to form diplomatic relations with China, the South China Sea contentions that arose in and around 2012 did not appear to dampen the consistent favorable public opinion toward China in Malaysia [20, 39].

Ranking in the middle of the nine countries (or regions) under study are Cambodia and South Korea. Public opinion in South Korea toward China has demonstrated a considerable level of consistency over the past year. Though China's public turned highly reactive toward South Korea's welcome of the Terminal High Altitude Area Defense (THAAD) anti-ballistic missile system from USA, the South Korean public appears to be rather rational in terms of its opinion of China and of the far east as a whole.

Cambodia has long enjoyed a cordial relationship with China, as China provides Cambodian political and economic elites the valuable opportunities for investment and financial support [28]. Thus, Cambodia manages to capitalize on the political resources afforded by China to further strengthen its domestic interests. Though scholars and observers alike worry that the extent to which Cambodia allies with China may subject Cambodia to China's influence as a patron and client, at the individual level, public opinion toward China's influence appears to be on the positive side in general. Future research is required to delve into the nuances among the country differences in terms of public opinion toward China.

\section{Robustness Check}

We employ a number of robustness check measures to ensure the validity of the above analysis. First, we employ an alternative approach to construct the "democratic awareness" variable. Instead of using the composite variable, a summation value of four independent survey questions, we here use another survey question that asks respondents whether or not they agree with the statement: "Democracy may have its problems, but it is still the best form of government." Logistic regression with the new "democratic awareness" variable constructed with this alternative approach shows similar results, except that the interaction effect between democratic awareness and perception of China's regime type no longer exists.

In the robustness check model, democratic awareness of Asia no longer bears statistical significance in impacting the turnout of the outcome variable. While Per_CN_Demo still plays a significant role in predicting the outcome variable and has a positive relationship with respondents' perception of China's influence, individual respondents' democratic awareness, under this new measure, no longer seems to factor into the effect. This shows that, while how Asians see China's political system still matters in how they see China's influence, individuals' acquaintance with democratic values does not necessarily matter in affecting the outcome variable.

In addition to controlling for the country dummies in the model, I run model 3 with the sub-sample of each individual country. This measure yields no markedly different result than what we have obtained from the above analysis. 


\section{Conclusion}

China's rise to the second largest economic power in the world, coupled with its increasingly more assertive foreign policy, has excited heated debates across the globe on how to see China's new position in the international stage and how to devise strategies to work with China. However, most of these discussions occur among scholars and political elites. How public opinion in other countries holds for China's rise is less studied in the literature. Public opinion is important in this scholarly dialogue in that, to be an international leader, a country has to be not only economically stronger but also politically swaying and culturally persuasive. While we know quite a bit about China's economic impact on its Asian neighbors, we are less certain how China's regime type as an authoritarian state affects its projection of power in Asia.

In this study, we reiterate the findings of the previous scholarly works that China's development model still remains the most significant parameter that wins China popular support in Asia. Developing economies in Asia tend to see China's rise as an advent for more economic cooperation in the region. A fast-growing economy China will not only facilitate systematic financial investments in these Asian economies, but higher income levels in China will also propel more Chinese tourists into tourism sites in Asia. However, China's economic development is not the only play card for its diplomatic outreach, as the effective domestic governance under the authoritarian Chinese Communist Party (CCP) is also part of the "development model" package.

We contend in this study, in addition to the economic evangelism of China's rise, that respondents' perception of China's political system might be the area where China can strive to improve as it aspires for more influence in Asia. We argue that China's one-party rule under the CCP keeps away a significant portion of Asians who are highly democratically aware and dogmatic in democratic principles. For these groups of Asians, their personal association with democratic and transparent governments leads them to suspect the true intents of opaque and authoritarian regimes. Despite the economic fuel that China has spilled into Asia, the ideological discrepancies that stand between China and their home countries, between China and their personal convictions, make it hard for them to see China's influence on Asia as positive.

This proposition is strongly supported by our empirical analysis with the latest Asian Barometer Survey data. Among other things, we find that China's regime type tarnishes China's international image in Asia most acutely among Asians who are well-informed of the central tenets of democracy. A holistic understanding of democratic values, such as competitive elections and freedom of press and speech, causes respondents in our survey to cast doubt on whether China's influence on their country is positive. As the respondents see China as more democratic, they tend to see China's influence as more positive. This finding is statistically significant, with all other variables accounted for in the various statistical models.

However, this effect no longer holds among Asians who are not democratically aware. For Asians who do not understand what democracy is or do not agree with the core precepts of democracy, they are more likely to see China in a positive light. The effect of China's regime type appears minimal (the lines are much flatter for values of Demo_Aware lower than 5 in Fig. 4). What deserves our attention is that there is only a tiny portion of Asians who are entirely ignorant of democracy. Most Asians have at least some degree of democratic values. This suggests that China faces a prominent challenge in "converting" the democratic hardliners in Asians to supporters of China. 
Given the findings, we reckon that future USA-China rivalry in the region will be affected by the two independent variables we identified in our research. The attractiveness of democracy and values of personal liberty, as the USA often represents and advocates, will likely find its portion of resonance in the region, while China's economic contribution to the region, if not entirely trampled down by the Coronavirus, will likely gain a significantly large audience, particularly to the impoverished and underdeveloped populations.

Miles to be journeyed in future research on how China would balance between the development model it so passionately proposes, economic development in particular such as the Belt and Road Initiative, and the political system that closely intertwined with such development but which invites serious reservation and even suspicion among the populations in other Asian countries.

\section{References}

1. Berinsky, Adam J. 2007. Assuming the Costs of War: Events, Elites, and American Public Support for Military Conflict. Journal of Politics 69(4), 975-997.

2. Berry W D, DeMeritt J H R, Esarey J. Testing for interaction in binary logit and probit models: Is a product term essential?[J]. American Journal of Political Science, 2010, 54(1): 248-266.

3. Bikales, Bill. China - Mongolia Relations, Trends and Recent Developments: A response to Morris Rossabi's discussion of China and Mongolia ties. March 18, 2018. < https://china.usc.edu/bill-bikaleschina-mongolia-relations-trends-and-recent-developments>, accessed May 29, 2019.

4. Bitzinger, Richard A. 2010. A New Arms Race? Contemporary Southeast Asia. 32(1), 50-69.

5. Brady, Anne-Marie. March 17, 2014. Chinese Foreign Policy: A New Era Dawns. The Diplomat.

6. Bueno de Mesquita, Bruce. 2000. Principles of International Politics. Sage Publications: Thousand Oaks, California.

7. Bünte M. Myanmar's Protracted Transition: Arenas, Actors, And Outcomes[J]. Asian Survey, 2016, 56(2): 369-391.

8. Burgess, Stephen F. 2016. Rising bipolarity in the South China Sea: the American rebalance to Asia and China's expansion. Contemporary Security Policy 37(1), 111-143.

9. Callahan, William A. (2012) China’s Strategic Futures. Asian Survey 52, (4): 617-642.

10. Chan, Irene and Mingjiang Li. 2015. New Chinese Leadership, New Policy in the South China Sea Dispute? Journal of Chinese Political Science 20, 35-50.

11. Chang-Liao, Nien-chung. 2016. China's New Foreign Policy under Xi Jinping. Asian Security 12(2), 8291.

12. Chen, Dingding and Xiaoyu Pu. 2013/14. Correspondence: Debating China's Assertiveness. International Security 38(3), 176-183.

13. Cho, Young Nam and Jong Ho Jeong. 2008. China's Soft Power: Discussions, Resources, and Prospects. Asian Survey 48(3), 453-472.

14. Cruz De Castro, Renato. 2016. The Philippines Discovers its Maritime Domain: The Aquino Administration's Shift in Strategic Focus from Internal to Maritime Security. Asian Security 12(2), 111-131.

15. Das, Shaheli. April 7, 2016. The Awakening of Xi's Chinese Dream. East Asia Forum.

16. Freedom House. 2018. <https://freedomhouse.org/report/freedom-world/freedom-world-2018>.

17. Friedberg, Aaron L. 2015. The Sources of Chinese Conduct: Explaining Beijing's Assertiveness. The Washington Quarterly 37(4), 133-150.

18. Hughes, Christopher. 2011. Reclassifying Chinese Nationalism: the geopolitik turn, Journal of Contemporary China 20(71): 601-620.

19. Jerden, Bjorn. 2014. The Assertive China Narrative: Why It Is Wrong and How So Many Still Bought into It. Chinese Journal of International Politics 47-88.

20. Kok-Kheng Yeoh, Emile and Siaw-Yien Loh. China-Malaysia Trade Relations, China-ASEAN Regional Cooperation and Malaysia's Policy Responses. ICS Working Paper. Institute of China Studies, University of Malaya. 
21. Mastro, Oriana Skylar. 2015. Why Chinese Assertiveness is Here to Stay. The Washington Quarterly 37(4), 151-170.

22. Mearsheimer, John. 2006. China's Unpeaceful Rise, Current History 105 (690), 160-162.

23. Nye, Joseph S., Jr. Soft power: the means to success in world politics (New York: Public Affairs), 2004

24. Nye, Joseph S., Jr. Public Diplomacy and Soft Power, The ANNALS of the American Academy of Political and Social Science, 616:94, pp.94-109, 2008.

25. Nye, Joseph S. July 10, 2015. The Limits of Chinese Soft Power. Project Syndicate.

26. Pemmaraju, Sreenivasa Rao. The South China sea arbitration (The Philippines v. China): Assessment of the award on jurisdiction and admissibility. Chinese Journal of International Law 15.2 (2016): 265-307.

27. Perper, Rosie. March 5, 2018. China is increasing its military spending by nearly $10 \%$. Business Insider goo.gl/hhQmmU. Accessed 14 March 2018

28. Po, Sovinda and Christopher B. Primiano. 2020. An 'Ironclad Friend': Explaining Cambodia's Bandwagoning Policy towards China. Journal of Southeast Asian Affairs. https://doi.org/10.1177 /2F1868103420901879

29. Primiano, Christopher B. 2017. "The Difference a Leader Makes: A Dramatic Change in ChinaPhilippines Relations." Asia Dialogue.

30. Putnam, Robert D. 1988. Diplomacy and Domestic Politics: The Logic of Two-Level Games. International Organization. 42 (3), 427-460.

31. Rapp-Hooper, Mira. 2016. Parting the South China Sea: How to Uphold the Rule of Law. Foreign Affairs Sept/Oct, 76-82.

32. Raymond, Greg. January 15, 2019. The Future of Thailand in an Era of Great Power Rivalry. Australia Institute of International Affairs. <https:/www.internationalaffairs.org.au/australianoutlook/futurethailand-era-great-power-rivalry/>, accessed May 29, 2019.

33. Roy, Denny. 1994. Hegemon on the Horizon? China's Threat to East Asian Security. International Security 19(1), 149-168.

34. Russett, Bruce and John Oneal. 2001. Triangulating Peace: Democracy, Interdependence and International Organizations. W.W. Norton and Company: NY.

35. Schweller, Randall L. and Xiaoyu Pu. After Unipolarity: China's Visions of International Order in an Era of U.S. Decline, International Security 36. No. 1 (2011): 41-72.

36. Shin, Doh Chull and Chong-Min Park. 2008. The Mass Public and Democratic Politics in South Korea: Exploring the Subjective World of Democratization in Flux in (eds.) Yun-han Chu, Larry Diamond, Andrew J. Nathan, and Doh Chull Shin, How East Asians View Democracy (Columbia University Press: New York), 39-60.

37. Tomz, Michael R. and Jessica L.P. Weeks. 2013. Public Opinion and the Democratic Peace. American Political Science Review 107(4), 849-865.

38. Waltz, Kenneth. 1979. Theory of International Politics. Waveland Press.

39. Wei, Chunjuan Nancy, and John Falzerano. Making Waves: Recent Developments of the South China Sea Disputes. Yonsei Journal Of International Studies (2016): 88.

40. Xiang, Jun, Christopher B. Primiano, and Wei-hao Huang. 2015. Aggressive or Peaceful Rise? An Empirical Assessment of China's Militarized Conflict, 1979-2010. Peace Economics, Peace Science and Public Policy. 21(3): 301-325.

41. Xinhua. March 17, 2013. President vows to bring benefits to people in realizing 'Chinese dream.

42. Yahuda, Michael. 2012. China’s Recent Relations with Maritime Neighbors. The International Spectator 47(2), 30-44.

43. Yahuda, M. (2013). China's New Assertiveness in the South China Sea. Journal of Contemporary China 22(81), 446-459

44. Yan, Xuetong. 2014. From Keeping a Low Profile to Striving for Achievements. Chinese Journal of International Politics. 153-184.

45. Yang, Yi Edward and Xinsheng Liu. 2012. The 'China Threat' Through the Lens of US Print Media: 1992-2006. Journal of Contemporary China 21(76), 695-711.

46. Zhao, Suisheng (2013). Foreign Policy Implications of Chinese Nationalism Revisited: the strident turn. Journal of Contemporary China 22(81), 535-553.

47. Zhao, Suisheng and Xiong Qi. (2016) Hedging and Geostrategic Balance of East Asian Countries toward China. Journal of Contemporary China 25(100): 485-499.

Publisher's Note Springer Nature remains neutral with regard to jurisdictional claims in published maps and institutional affiliations. 